\title{
A FAMILY STUDY IN STILL'S DISEASE*
}

BY

\author{
BARBARA M. ANSELL, E. G. L. BYWATERS, AND J. S. LAWRENCE \\ From the M.R.C. Rheumatism Research Unit, Taplow, and the E.R.C. Field Unit, Manchester
}

Familial studies in inflammatory polyarthritis indicate strong hereditary factors, particularly in relationship to the serological tests (Lawrence and Ball, 1958). In a single kindred of some 3,000 persons reported briefly by Whittinghill, Hendricks, Taylor, and Thorp (1958), rheumatoid arthritis was distributed independently of spondylitis and Still's disease. The ten spondylitics had higher than random frequencies of other cases of spondylitis and of Still's disease among their first-degree relatives, suggesting a genetic origin for this dual susceptibility. The five cases of Still's disease had, as their close relatives, spondylitics rather than persons with other forms of juvenile or adult rheumatoid arthritis. Precise details of the criteria used for the diagnosis of Still's disease in this study are not available, and the evaluation of this relationship is complicated by the fact that a transient attack of polyarthritis precedes the onset of spondylitis in about 25 per cent. of patients, often some years before the spondylitic phase (Hollister and Engleman, 1958).

Conflicting results have been obtained with serological tests in Still's disease. We have found 45 per cent. of such patients to have a positive Rose-Waaler test on at least one occasion during a 4- to 10-year follow-up, although only 13 per cent. were positive on the first test (Bywaters, Carter, and Scott, 1959a). McEwen, Ziff, Carmel, Ditata, and Tanner (1958), using the euglobulin fraction for the S.C.A.T., found 58 per cent. positive, but with their inhibition test 94 per cent. were positive.

With a view to elucidating this problem further, a group of patients with Still's disease admitted to the Canadian Red Cross Hospital, Taplow, have been used as probands for a family study.

* Paper given at a meeting of the Heberden Society in December,

\section{Method}

The criteria used to determine the inclusion of patients as probands in this study were:

(a) That they lived within 15 miles of the Canadian Red Cross Memorial Hospital at Taplow or within 10 miles of Hammersmith Hospital, London, the two centres at which examinations were carried out.

(b) That they had been in-patients before January, 1960.

(c) That they had rheumatoid arthritis starting before age 16 with evidence of arthritis in four or more joints for a minimum of 3 months, or (in a few cases in which fewer than four joints were affected), with a biopsy of synovial membrane showing hyperplasia with underlying round-cell infiltration and plasma cells without evidence of tuberculosis or other infection.

In no case was there evidence of associated disease, such as ulcerative colitis, psoriasis, systemic lupus erythematosus, or ankylosing spondylitis either on initial examination or at follow-up to the time of the survey, but radiological sacro-iliac changes without evidence of spondylitis were not considered to be a reason for exclusion. Altogether there were 93 probands (35 male and 58 female). In 24 the disease had started before the age of 5 years, 27 between 5 and 10 years, and the remaining 42 between 10 and 16 years.

The relatives included were siblings aged 15 or over, parents, and grandparents living in the same area. All relatives who were willing to co-operate were questioned about a history of rheumatic and other complaints in general and specifically about joint pain and swelling, morning stiffness, and previous rheumatic fever or gout, as well as cardiovascular, chest, stomach, urinary, and eye troubles. They then had a clinical examination of the musculo-skeletal system with radiological examination according to a scheme designed to avoid radiation hazards (hands, feet, and lateral cervical spine in all cases, lateral lumbar spine over age 35 , and posteroanterior of pelvis in all males and in females over age 45). 
Radiation risks were further minimized by coning to a minimal area and by the use of a protective screen for the gonads in males. A sample of blood was tested by the sheep cell agglutination method of Rose, Ragan, Pearce, and Lipman (1948) at Taplow and that of Ball (1950) at Manchester.

The titres obtained in Manchester were, in general, one dilution higher than at Taplow and, allowing for this, there were only three instances in the 254 sera tested at both units where there was more than one dilution difference between the two results.

\section{Completion Rate}

The 93 probands had a total of 368 living relatives in the above categories (160 male and 208 female), but 64 lived outside this area, and the whereabouts of ten were not known. In addition, there were 239 mostly grandparents, who had died before the start of the survey.

Of the 304 relatives (133 male and 171 female) who were living in the area, 27 had neither an $x$ ray nor a blood test, and the completion rate was thus 91 per cent. Of the 277 relatives examined, 49 were grandparents, 153 parents, and 75 siblings. All except three of them had both radiological examination and a serum test (Table I). The sex and age distribution of the relatives is also shown in Table $I$. There were no offspring over the age of 15 . In both sexes the largest numbers were in the 45-54 age group, mainly parents. There was also a large number in the 15-24 age group, mainly siblings.

Of the 27 not fully examined, sixteen were over 65 years of age and were too frail to come to hospital for $x$ ray, but most of these were seen or, when this was not possible, their doctors were questioned and none had obvious evidence of arthritis. Similar inquiries were made about the younger relatives not fully examined, and only one, a man of 44 , had palindromic rheumatism.

In order to make certain that the selection of the material had not prejudiced the results, a survey of the first-degree relatives of the 119 patients with Still's disease admitted from elsewhere in Great Britain at the $\frac{C}{\partial}$ same time as the probands was undertaken. This $\overline{\bar{\omega}}$ included all parents and siblings aged 15 years and over $\vec{\oplus}$ who were resident in England. These were visited in $\triangle$ their homes and subjected to the same general questioning and examination, and a serum sample was obtained. The completion rate was 87 per cent. compared with 91 per cent. in the study area.

\section{Results}

Polyarthritis

Clinical inflammatory polyarthritis was found at the time of examination in nine ( 7 per cent.) of the 120 male relatives examined. The expected number calculated, according to this age distribution, from the Leigh and Wensleydale random population $\vec{c}$ samples (Lawrence and Bennett, 1960) was 3.62. Of the 157 female relatives who were examined, thirteen ( 8 per cent.) had clinical polyarthritis compared with an expected number of 7.52. The $\mathbb{\Phi}$ difference between the actual and expected number is highly significant $\left(\chi^{2}=7 \cdot 3 ; p<\cdot 01\right)$. The condition was of earlier onset in both male and female relatives than in the random sample, none of whom would be expected to have polyarthritis before age 35 (Table II).

TABLE I

COMPLETENESS OF SAMPLE OF RELATIVES OF PROBANDS WITH STILL'S DISEASE RESIDENT IN AREA

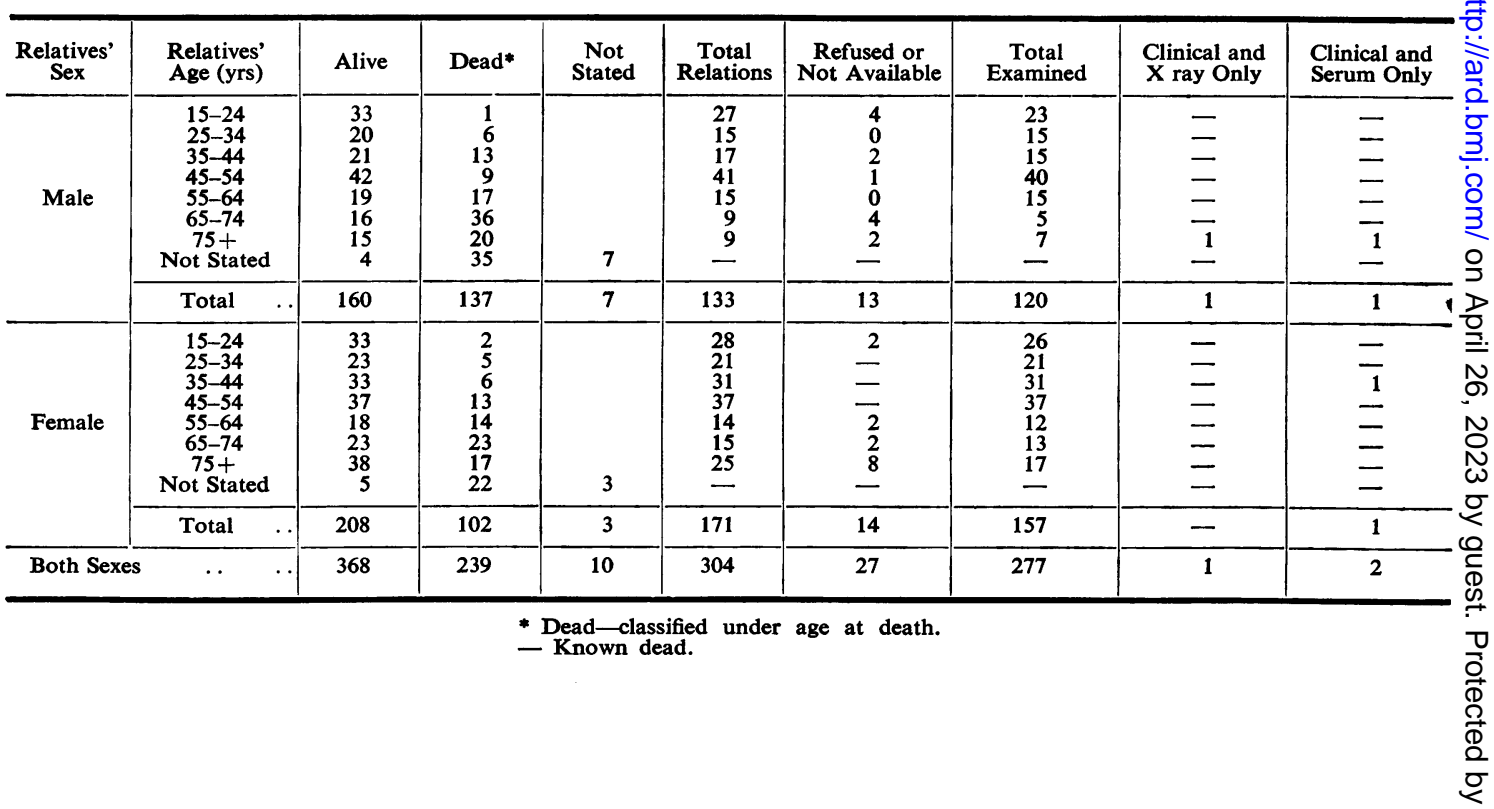


TABLE II

CLINICAL POLYARTHRITIS IN RELATIVES COMPARED WITH THAT FOUND IN RANDOM POPULATION STUDIES

\begin{tabular}{|c|c|c|c|c|c|c|c|c|}
\hline \multirow{2}{*}{ Sex } & \multirow{2}{*}{ Age (yrs) } & \multicolumn{6}{|c|}{ Present Arthritis Grade } & \multirow{2}{*}{$\frac{\text { Expected }}{2-4}$} \\
\hline & & Total & 0 & 1 & 2 & 3 & 4 & \\
\hline \multirow[t]{2}{*}{ Male } & $\begin{array}{c}15-24 \\
25-34 \\
35-44 \\
45-54 \\
55-64 \\
65-74 \\
75+\end{array}$ & $\begin{array}{r}23 \\
15 \\
15 \\
40 \\
15 \\
5 \\
7\end{array}$ & $\begin{array}{r}21 \\
13 \\
15 \\
34 \\
10 \\
2 \\
5\end{array}$ & $\begin{array}{l}\overline{2} \\
2 \\
3 \\
3 \\
1\end{array}$ & $\begin{array}{l}\overline{-} \\
\frac{2}{2} \\
\frac{2}{1}\end{array}$ & $\begin{array}{l}- \\
\frac{2}{z} \\
-\end{array}$ & $\begin{array}{l}2 \\
- \\
-\end{array}$ & $\begin{array}{l}0 \cdot 13 \\
0 \cdot 34 \\
0 \cdot 33 \\
1 \cdot 6 \\
0 \cdot 5 \\
0 \cdot 15 \\
0 \cdot 58\end{array}$ \\
\hline & Total $\ldots \quad \ldots$ & 120 & 100 & 11 & 5 & 2 & 2 & $3 \cdot 62$ \\
\hline \multirow[t]{2}{*}{ Female } & $\begin{array}{c}15-24 \\
25-34 \\
35-44 \\
45-54 \\
55-64 \\
65-74 \\
75+\end{array}$ & $\begin{array}{l}26 \\
21 \\
31 \\
37 \\
12 \\
13 \\
17\end{array}$ & $\begin{array}{r}25 \\
26 \\
28 \\
33 \\
8 \\
7 \\
10\end{array}$ & $\begin{array}{l}0 \\
0 \\
0 \\
2 \\
4 \\
3 \\
4\end{array}$ & $\begin{array}{l}1 \\
0 \\
1 \\
1 \\
0 \\
2 \\
3\end{array}$ & $\begin{array}{l}-1 \\
\mathbf{1} \\
1 \\
0 \\
1 \\
\end{array}$ & $\begin{array}{l}- \\
0 \\
0 \\
0 \\
0 \\
0 \\
\end{array}$ & $\begin{array}{l}0 \\
0.48 \\
1 \cdot 3 \\
2 \cdot 34 \\
0 \cdot 87 \\
1 \cdot 69 \\
0 \cdot 84\end{array}$ \\
\hline & Total $\ldots$ & 157 & 131 & 13 & 8 & 5 & 0 & $7 \cdot 52$ \\
\hline
\end{tabular}

MALES. - Of the nine male relatives with polyarthritis, four were diagnosed as cases of ankylosing spondylitis; one had frank ankylosing spondylitis without peripheral joint disease, and three had both ankylosing spondylitis and peripheral arthritis-two of these had had iritis.

A fifth male relative had been diagnosed as a case of lumbar disk degeneration and possible spondylitis, and the latter was subsequently confirmed by radiological examination.

As the prevalence of spondylitis was 0.3 per cent. in the random population sample, one case would have been expected in a sample of 277 persons $(p=<\cdot 01)$. No instances of combined spondylitis and peripheral arthritis were encountered in the Leigh and Wensleydale population samples.

Of the remaining five polyarthritic males, one had a history of two attacks of gout and the other four were diagnosed as cases of rheumatoid arthritis. None of these were sero-positive.

FeMALES.-One of the thirteen females had polyarthritis associated with ulcerative colitis and was sero-negative. The remaining twelve had been diagnosed as cases of rheumatoid arthritis, and of these only three were sero-positive.

Radiological Confirmation was obtained in six of the nine male relatives with clinical polyarthritis, it was doubtful in one spondylitic, and absent in one peripheral arthritic, and in the case of gout. It was present in eight of the thirteen females, two of the others being sibs with early polyarthritis and three grandmothers, in whom only degenerative joint changes were noted on the radiographs.
Past Polyarthritis.-A history of past polyarthritis was given by four male relatives and by seven females. The expected numbers calculated according to age distribution from the Leigh and Wensleydale population sample were five male and eleven female. There was thus no excess of past polyarthritis in the relatives.

\section{Radiological Changes}

For comparison with the relatives, a control sample of $275 x$ rays was taken from the Leigh and Wensleydale surveys. These were stratified for age and sex to match the relatives' $x$ rays, and also for clinical rheumatoid arthritis and seropositivity to match the total Leigh-Wensleydale random sample. These $x$ rays were mixed with relatives' $x$ rays and were then read blind for rheumatoid arthritis, osteo-arthrosis, and disk degeneration, each being graded 0-4 for each group of joints (Kellgren and Lawrence, 1957a, b). The groups of joints read were distal inter-phalangeal, proximal inter-phalangeal, metacarpo-phalangeal, carpo-metacarpal, wrists, cervical spine, tarsi, lateral metatarso-phalangeal, and first metatarsophalangeal in all cases, and lumbar spine and hips where available. This method of control was used to avoid re-reading the entire Leigh-Wensleydale random sample.

Hands.--Erosive arthritis Grade 2-4 was found in the hands in three male relatives and in two male controls. In two of the former it was severe and in one moderate, and of the latter, one had minimal and one had moderate disease. In the females the 
difference was more striking, sixteen relatives having erosive arthritis in the hands but only four controls $\left(\chi^{2}=7 \cdot 2 ; p=<\cdot 01\right)$ (Table III).

Feet.-Erosive arthritis Grade 2-4 was found in the feet in three male relatives (in one severe), and in two male controls (neither severe). Twelve of the female relatives had erosive arthritis in the feet (in two severe), and six female controls (none severe) (Table III).

TABLE III

EROSIVE ARTHRITIS IN RELATIVES AND CONTROLS

\begin{tabular}{|c|c|c|c|c|c|}
\hline \multirow{3}{*}{ Sex } & \multirow{3}{*}{ Total } & \multicolumn{4}{|c|}{ Erosions Grade 2-4 } \\
\hline & & \multicolumn{2}{|c|}{ Hands } & \multicolumn{2}{|c|}{ Feet } \\
\hline & & Relatives & Controls & Relatives & Controls \\
\hline Male & 120 & 3 & 2 & 3 & 2 \\
\hline Female & 157 & 16 & 4 & 12 & 6 \\
\hline
\end{tabular}

Cervical Spine.-Rheumatoid arthritis of the cervical spine w2s graded in accordance with the criteria of Sharp, Purser, and Lawrence (1958). Six of the male relatives had Grade 2-4 changes in the cervical spine compared with three controls, and five female relatives compared with eleven female controls. There was thus no evidence that cervical rheumatoid arthritis, as defined by Sharp and others, is genetically related to Still's disease. Our experience (J.S.L.) with the relatives of adult rheumatoid arthritics has been similar. In this connexion it should be noted that Sharp and others (1958) found this radiological picture related only to sero-positive rheumatoid arthritis in adults.

Sacro-iliac Joints.-As the random population samples from Leigh and Wensleydale had an $x$ ray of the pelvis only from age 55 onwards, controls from this source were not available in the younger age groups. Accordingly, a control group matchect. by age and sex with the probands and relatives was: picked from general hospital patients (Hammer smith) up to age 54, who had had renal tract $x$ rayso during the year 1959 to 1960 , and the postmicturitiono bladder film was used for assessing the sacro-iliach joints. In age groups up to 24 there were insufficient他 controls from this source and accordingly a group of eleven $x$ rays of convalescent rheumatic fever patients was added. These had been taken previously $\vec{\rho}$ for another investigation. All the control $x$ rays $\vec{s}$ were mixed with those of the probands and relatives before reading and were read "blind". Radio logical evidence of sacro-iliitis was considered to be present when there were erosions of the subchondrat bone with sclerosis and diminished joint space an were graded 0-4.

Definite sacro-iliitis Grade 2-4 was found in theo most recent film in eight of the male and thirteen of the female probands (Table IV). In the series of age-matched controls, only one male and threes females had this grade of sacro-iliitis, and there waș thus five times the expected amount of sacro-iliitis in patients with Still's disease and it was found equally in males and females. Table V (opposite) shoß/5o that sacro-iliitis Grade 2-4 was found in ele (10 per cent.) of the male relatives and in the ( 3 per cent.) of the controls $\left(\chi^{2}=4 \cdot 6 ; p=\cdot 0\right.$ ) Sacro-iliitis was encountered in nine (15 per cent. of the female relatives and in seven (11 per cent. $\bar{Q}$ of the female controls: not a significant difference because of the high prevalence of sacro-iliitis in? the female controls.* In all the age groupsi examined there was a greater prevalence of sacro 3 iliitis in the female than in the male controls, bue this sex difference in incidence is not large enough. to be significant.

* It must be realized that these are hospital controls and therefore do not represent the incidence of sacro-iliitis in the population A further study is at present in progress to determine this.

TABLE IV

SACRO-ILIAC JOINT CHANGES IN PROBANDS AND CONTROLS

\begin{tabular}{|c|c|c|c|c|c|c|c|c|c|c|c|c|c|c|}
\hline \multirow{3}{*}{$\begin{array}{c}\text { Age } \\
\text { (yrs) }\end{array}$} & \multicolumn{7}{|c|}{ Male } & \multicolumn{7}{|c|}{ Female* } \\
\hline & \multirow[t]{2}{*}{ Total } & \multicolumn{3}{|c|}{ Controls } & \multicolumn{3}{|c|}{ Probands } & \multirow[t]{2}{*}{ Total } & \multicolumn{3}{|c|}{ Controls } & \multicolumn{3}{|c|}{ Probands } \\
\hline & & 0 & 1 & $2-4$ & 0 & 1 & $2-4$ & & 0 & 1 & $2-4$ & 0 & 1 & $2-4$ \\
\hline $\begin{array}{r}0-4 \\
5-9 \\
10-14 \\
15-24 \\
25-34\end{array}$ & $\begin{array}{r}2 \\
3 \\
9 \\
20 \\
1\end{array}$ & $\begin{array}{r}2 \\
3 \\
9 \\
14 \\
1\end{array}$ & $\begin{array}{l}0 \\
0 \\
0 \\
5 \\
0\end{array}$ & $\begin{array}{l}0 \\
0 \\
0 \\
1 \\
0\end{array}$ & $\begin{array}{l}1 \\
3 \\
6 \\
9 \\
0\end{array}$ & $\begin{array}{l}0 \\
0 \\
2 \\
6 \\
0\end{array}$ & $\begin{array}{l}1 \\
0 \\
1 \\
5 \\
1\end{array}$ & $\begin{array}{r}2 \\
8 \\
19 \\
25 \\
2\end{array}$ & $\begin{array}{r}2 \\
8 \\
17 \\
15 \\
2\end{array}$ & $\begin{array}{l}0 \\
0 \\
2 \\
7 \\
0\end{array}$ & $\begin{array}{l}0 \\
0 \\
0 \\
3 \\
0\end{array}$ & $\begin{array}{r}1 \\
8 \\
12 \\
9 \\
0\end{array}$ & $\begin{array}{l}0 \\
0 \\
3 \\
8 \\
2\end{array}$ & $\begin{array}{l}1 \\
0 \\
4 \\
8 \\
0\end{array}$ \\
\hline Total .. & 35 & 29 & 5 & 1 & 19 & 8 & 8 & 56 & 44 & 9 & 3 & 30 & 13 & $13=$ \\
\hline
\end{tabular}


TABLE V

SACRO-ILIITIS IN RELATIVES RELATED TO GRADE IN PROBANDS

\begin{tabular}{|c|c|c|c|c|c|c|c|c|}
\hline \multirow{2}{*}{$\begin{array}{l}\text { Sex of } \\
\text { Relatives }\end{array}$} & \multirow{2}{*}{$\begin{array}{l}\text { Grade of Sacro-iliitis } \\
\text { in Proband }\end{array}$} & \multirow{2}{*}{$\begin{array}{l}\text { No. of Relatives } \\
X \text {-rayed }\end{array}$} & \multicolumn{5}{|c|}{ Grade of Change in Relatives } & \multirow{2}{*}{$\begin{array}{c}\text { Percentage Grade } 2-4 \\
\text { in Relatives }\end{array}$} \\
\hline & & & 0 & 1 & 2 & 3 & 4 & \\
\hline \multirow{5}{*}{ Male } & 0 & 63 & 40 & 17 & 5 & 1 & 0 & 9 \\
\hline & 1 & 21 & 15 & 4 & 1 & 1 & 0 & 9 \\
\hline & $2-4$ & 21 & 14 & 4 & $\mathbf{0}$ & 2 & 1 & 14 \\
\hline & Total Relatives & 105 & 69 & 25 & 6 & 4 & 1 & 10 \\
\hline & Total Controls & 108 & 82 & 23 & 3 & 0 & 0 & 3 \\
\hline \multirow{5}{*}{ Female } & 0 & 36 & 26 & 8 & 2 & 0 & 0 & 6 \\
\hline & 1 & 12 & 10 & 0 & 2 & 0 & 0 & 17 \\
\hline & $2-4$ & 13 & 8 & 0 & 4 & 1 & 0 & 38 \\
\hline & Total Relatives & 61 & 44 & 8 & 8 & 1 & 0 & 15 \\
\hline & Total Controls & 68 & 47 & 10 & 6 & 1 & 0 & 11 \\
\hline
\end{tabular}

Grade of Sacro-iliitis in Proband.-When the relatives were divided into two groups depending on the grade of sacro-iliitis in the proband, it was found that there was a greater prevalence of definite sacro-iliitis in the relatives of those probands who had sacro-iliitis Grade 2-4 (Table V). This difference was striking in the female relatives and, despite the small numbers concerned, was significant $(p=.04)$. Not only sacro-iliitis but also clinical polyarthritis Grade 2-4 was slightly more common in the relatives of probands with definite sacroiliitis (Table VI). Clinical spondylitis (five cases all male) was found only in the relatives of probands, with definite or doubtful sacro-iliitis. Erosive arthritis of the hands was found in two ( 9 per cent.) of the male relatives of probands with definite sacro-iliitis, but in only one ( 1 per cent.) of the remainder. Of the female relatives of probands with definite sacro-iliitis, five (17 per cent.) had erosive arthritis in the hands compared with twelve ( 9 per cent.) of the remainder. Similarly, in the feet, there was more erosive arthritis in the relatives of probands with sacro-iliitis. In the cervical spine, changes typical of rheumatoid arthritis were found in five (17 per cent.) of male relatives of probands with sacro-iliitis, in two (8 per cent.) of male relatives of probands with doubtful sacro-iliitis, and in none of the remainder. In the females the reverse applied, the five with cervical rheumatoid arthritis all being relatives of probands without sacro-iliitis. The difference in males is significant at the 5 per cent. level.

Sex of Proband.-When the relatives were divided according to the sex of the proband, more clinical polyarthritis was found in the relatives of the male than of the female probands, although these relatives and particularly the males were younger $\left(\chi^{2}=3 \cdot 9 ; p=\cdot 05\right)$ (Table VII, overleaf). Radiological erosions in the hands were found in three of the male relatives of male probands, but in none of the male relatives of female probands. Sacro-iliitis, similarly, was more common in the male relatives of male probands. The female relatives had similar amounts of disease clinically and radiologically, no matter whether the proband was male or female.

TABLE VI

RELATIONSHIP OF SACRO-ILIITIS IN PROBANDS TO ARTHRITIS IN RELATIVES

\begin{tabular}{|c|c|c|c|c|c|c|c|}
\hline \multirow[b]{2}{*}{ Sex of Relatives } & \multirow{2}{*}{$\begin{array}{c}\text { Grade of } \\
\text { Sacro-iliitis } \\
\text { in Probands }\end{array}$} & \multicolumn{6}{|c|}{ Percentage Relatives with Grade $2-4$ Sacro-iliitis } \\
\hline & & Total & $\begin{array}{c}\text { Clinical } \\
\text { Rheumatoid } \\
\text { Arthritis }\end{array}$ & $\underset{\text { Hands }}{X \text { ray }}$ & $\begin{array}{c}X \text { ray } \\
\text { Feet }\end{array}$ & $\begin{array}{l}X \text { ray } \\
\text { Neck }\end{array}$ & $\begin{array}{c}X \text { ray } \\
\text { Sacro-iliac } \\
\text { Joints }\end{array}$ \\
\hline \multirow{2}{*}{ Male } & $0-1$ & 95 & 6 & 1 & 0 & 2 & 9 \\
\hline & $2-4$ & 25 & 12 & 9 & 12 & 17 & 14 \\
\hline \multirow{2}{*}{ Female } & $0-1$ & 127 & 8 & 9 & 6 & 4 & 9 \\
\hline & $2-4$ & 30 & 10 & 17 & 13 & 0 & 38 \\
\hline
\end{tabular}


TABLE VII

RELATIONSHIP OF PROBAND'S SEX TO DISEASE IN RELATIVES

\begin{tabular}{|c|c|c|c|c|c|c|c|}
\hline \multicolumn{4}{|c|}{ Sex } & \multirow{2}{*}{ Total Relatives } & \multicolumn{3}{|c|}{ Disease in Relatives (per cent.) } \\
\hline Proband & Rel & ves & & & Polyarthritis & Grade 2-4 Arthritis & Sacro-iliitis \\
\hline \multirow{2}{*}{ Male } & Male & . & $\cdots$ & 42 & 14 & 7 & 18 \\
\hline & Female & $\cdots$ & $\cdots$ & 54 & 9 & 9 & 12 \\
\hline \multirow{2}{*}{ Female } & Male & $\cdots$ & $\cdots$ & 78 & 4 & 0 & 6 \\
\hline & Female & . & $\cdots$ & 103 & 8 & 11 & 13 \\
\hline
\end{tabular}

31 relatives showed no inflammatory polyarthritis clinically, but did show erosive changes radiologically. Fourteen of these had sacro-iliac changes alone: five (all grandparents) had erosive changes in more than one site, six had changes in the hands only, five in the cervical spine only, and one in the feet only.

Osteo-arthrosis.-This (based on all the $x$ rays taken) was present in at least one group of joints in 54 per cent. of both male and female relatives, but only three males and $\mathbf{2 5}$ females had involvement of five or more groups of joints. The expected number as, judged from the population sample, is eight males and 23 females. There was thus no evidence that the families of Still's disease probands had any increased susceptibility to osteo-arthrosis. Cervical disk degeneration Grade 2-4 was present in 49 male relatives and 66 female relatives. The expected numbers from the control $x$ rays were 52 male and 61 females, so that there was no substantial difference. The degree of severity was also similar, but there were a greater number of relatives in whom more than three disks were affected than in the controls (the difference is not significant, $\left.\chi^{2}=2 \cdot 8 ; p=\cdot 1\right)$.
Lumbar Spine.-Only 66 male and 85 female relatives and 69 male and 75 female controls had $\stackrel{0}{i}$ lumbar spine $x$ rays as these were omitted in the.younger age group. Lumbar disk degeneration $i$ Grade 2-4 was present in 46 of the male relatives and in the same number of controls, and in $43 \circ$ (51 per cent.) of the female relatives and in $35^{\circ}$ (47 per cent.) of the controls. There was thus no $\overrightarrow{c s}$ substantial difference in the number of persons $\mathbb{D}$ showing disk degeneration nor in the severity or $\mathbb{\mathbb { Q }}$ number of disks involved.

\section{Sensitized Sheep Cell Agglutination Test (S.C.A.}

This was positive (4-9) in only one of the 119 meico relatives tested, whereas the expected number for the male population of this age distribution calculated from the Leigh and Wensleydale population. sample would be four. Four of the 152 female relatives tested were positive, whereas the expected $\stackrel{\varrho}{\Rightarrow}$ number would be seven (Table VIII). The fouro positive females were all between the ages 35 and $64 . \frac{7}{5}$ This difference fails to be significant. There was thus no evidence of a familial aggregation of the sheep cell factor in Still's disease.

TABLE VIII

S.C.A.T. IN RELATIVES OF PROBANDS WITH STILL'S DISEASE

\begin{tabular}{|c|c|c|c|c|c|c|c|c|c|c|c|c|c|c|c|c|c|c|c|c|c|c|c|c|c|c|}
\hline \multirow{3}{*}{$\begin{array}{c}\text { Age } \\
(\mathrm{yrs})\end{array}$} & \multicolumn{13}{|c|}{ Males } & \multicolumn{13}{|c|}{ Females } \\
\hline & \multirow{2}{*}{ Total } & \multicolumn{4}{|c|}{ Sero-negative } & \multicolumn{6}{|c|}{ Sero-positive } & \multirow{2}{*}{$\begin{array}{c}\text { Not } \\
\text { Stated }\end{array}$} & \multirow{2}{*}{$\begin{array}{c}\text { Expected } \\
\text { Number } \\
4+\end{array}$} & \multirow{2}{*}{ Total } & \multicolumn{4}{|c|}{ Sero-negative } & \multicolumn{6}{|c|}{ Sero-positive } & \multirow{2}{*}{$\underset{\text { Stated }}{\text { Not }}$} & \multirow{2}{*}{$\begin{array}{l}\text { Expected } \\
\text { Number } \\
4+\end{array}$} \\
\hline & & 0 & 1 & 2 & 3 & 4 & 5 & 6 & 7 & 8 & 9 & & & & 0 & 1 & 2 & 3 & 4 & 5 & 6 & 7 & 8 & 9 & & \\
\hline $\begin{array}{c}15-24 \\
25-34 \\
35-44 \\
45-54 \\
55-64 \\
65-74 \\
75+\end{array}$ & $\begin{array}{r}23 \\
15 \\
15 \\
40 \\
15 \\
5 \\
7\end{array}$ & \begin{tabular}{r|}
16 \\
12 \\
12 \\
31 \\
10 \\
3 \\
5
\end{tabular} & $\begin{array}{l}7 \\
3 \\
3 \\
7 \\
5 \\
1 \\
1\end{array}$ & $\begin{array}{l}\bar{z} \\
\overline{1} \\
\overline{-}\end{array}$ & $\begin{array}{l}- \\
\bar{z} \\
\overline{1} \\
-\end{array}$ & $\begin{array}{l}- \\
- \\
- \\
-\end{array}$ & $\begin{array}{l}- \\
- \\
- \\
-\end{array}$ & $\begin{array}{l}- \\
- \\
- \\
-\end{array}$ & $\begin{array}{l}- \\
- \\
- \\
- \\
-\end{array}$ & $\begin{array}{l}- \\
- \\
- \\
-\end{array}$ & $\begin{array}{l}- \\
- \\
z \\
-\end{array}$ & $\begin{array}{l}z \\
z \\
z\end{array}$ & $\begin{array}{l}0 \cdot 2 \\
0 \cdot 5 \\
0 \cdot 3 \\
1 \cdot 8 \\
0 \cdot 4 \\
0 \cdot 6 \\
0 \cdot 5 \\
\end{array}$ & $\begin{array}{l}26 \\
21 \\
31 \\
37 \\
12 \\
13 \\
17\end{array}$ & \begin{tabular}{r|r}
12 & 17 \\
24 \\
26 \\
8 \\
8 \\
13 \\
\end{tabular} & $\begin{array}{r}10 \\
3 \\
5 \\
10 \\
2 \\
5 \\
3 \\
\end{array}$ & $\begin{array}{r}2 \\
1 \\
1 \\
- \\
- \\
\end{array}$ & $\begin{array}{l}2 \\
\text { - } \\
\text { - } \\
- \\
\end{array}$ & $\begin{array}{l}- \\
- \\
\frac{2}{2} \\
-\end{array}$ & $\begin{array}{l}- \\
\overline{1} \\
1 \\
- \\
-\end{array}$ & $\begin{array}{l}- \\
- \\
- \\
- \\
-\end{array}$ & $\begin{array}{l}= \\
= \\
= \\
=\end{array}$ & $\begin{array}{l}- \\
- \\
- \\
-\end{array}$ & $\begin{array}{l}- \\
- \\
- \\
- \\
-\end{array}$ & $\begin{array}{l}- \\
z \\
z\end{array}$ & 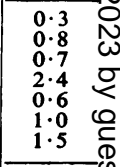 \\
\hline Total ... & 120 & 89 & 27 & 1 & 1 & 1 & - & - & - & - & - & 1 & $4 \cdot 3$ & 157 & 108 & 38 & 5 & 2 & 2 & 2 & - & - & - & - & - & $7 \cdot 3$ \\
\hline
\end{tabular}


Relationship of Sero-Positivity in Probands to Arthritis in Relatives. - Of the 93 probands, 27 had a positive sheep cell test at some time during the course of their illness, although only eight of them had persistently positive titres. These 27 probands had 31 male and 46 female relatives, and clinical rheumatoid arthritis was found in 3 per cent. of the males and 7 per cent. of the females. Among the relatives of the 66 sero-negative probands, 9 per cent. of both males and females had clinical rheumatoid arthritis (Table IX). There was thus no evidence that sero-positivity in the proband increased the liability to rheumatoid arthritis in his family.

Only one of the 29 male relatives of sero-positive probands who had $x$ rays of the sacro-iliac joints had definite evidence of sacro-iliitis, compared with fourteen of the 77 male relatives of sero-negative probands, a significant difference. No such difference was found in the female relatives.

The eight probands with a persistently positive S.C.A.T. had 29 relatives, none of whom was seropositive, and clinical rheumatoid arthritis was found in only one, a female aged 40 , in whom it was also confirmed radiologically in the hands and feet. Erosive arthritis was seen in the hands and feet of one other relative, a female aged 85 , who had been diagnosed as a case of degenerative joint disease, and in the hands only of a second female relative aged 59 who also showed sacro-iliac changes. No other relative in this group showed definite sacroiliitis.

\section{Family Size}

The most frequent number of children in the families of probands with Still's disease investigated was two-there were 28 such families compared with 27 where there was only one child, and with eleven where there were three, eleven where there were four, and fourteen with more children. In the random sample, the most frequent family size was two when females with no children were excluded.

\section{Cause of Death in Relatives}

Only two siblings of the 93 Still's disease probands had died, one from subacute bacterial endocarditis and old rheumatic heart disease and the other from peritonitis after a perforated appendix. Seven of the fathers and four of the mothers had died; the causes of death were in no way remarkable. Of the grandparents only fifteen had died below the age of 50 .

\section{Representability of Sample}

There were 267 first-degree relatives (133 males and 134 females) of 119 cases of Still's disease living outside the survey area, compared with 228 (107 males and 121 females) inside the area. The age distribution was slightly different in that there were more young people (15 to 24 years) outside the area.

Six male and five female relatives outside the area were found to have definite inflammatory polyarthritis as compared with eight male and seven female relatives inside the area. Of the six males with inflammatory polyarthritis outside the study area, one was diagnosed as a case of gout, one of ankylosing spondylitis, and one of palindromic rheumatism, and the remaining three of rheumatoid arthritis; this may be compared with one case of gout, one of ankylosing spondylitis, three of ankylosing spondylitis with peripheral arthritis, and three of rheumatoid arthritis inside the area. All the twelve affected females inside and outside the area had rheumatoid arthritis.

TABLE IX

CLINICAL POLYARTHRITIS, EROSIVE ARTHRITIS, S.C.A.T., AND SACRO-ILIITIS IN RELATIVES RELATED TO S.C.A.T. OF PROBAND

\begin{tabular}{|c|c|c|c|c|c|c|c|c|c|c|c|}
\hline \multirow{3}{*}{$\begin{array}{l}\text { S.C.A.T. } \\
\text { of Proband }\end{array}$} & \multirow{3}{*}{$\begin{array}{c}\text { Sex of } \\
\text { Relatives }\end{array}$} & \multicolumn{10}{|c|}{ Findings in Relatives } \\
\hline & & \multirow[t]{2}{*}{ Total } & \multicolumn{2}{|c|}{$\begin{array}{c}\text { Arthritis } \\
\text { Grade 2-4 }\end{array}$} & \multicolumn{2}{|c|}{$\begin{array}{l}\text { Erosions Hands and } \\
\text { Feet Grade } 2-4\end{array}$} & \multicolumn{2}{|c|}{$\begin{array}{l}\text { Positive } \\
\text { S.C.A.T. }\end{array}$} & \multirow[t]{2}{*}{$\underset{X \text {-rayed }}{\text { No. }}$} & \multicolumn{2}{|c|}{$\begin{array}{l}\text { Sacro-iliitis } \\
\text { Grade } 2-4\end{array}$} \\
\hline & & & No. & Per cent. & No. & Per cent. & No. & Per cent. & & No. & Per cent. \\
\hline \multirow{2}{*}{ Positive at least Once } & Male & 31 & 1 & 3 & 1 & 3 & 0 & - & 29 & 1 & 3 \\
\hline & Female & 46 & 3 & 7 & 7 & 15 & 1 & 2 & 24 & 4 & 17 \\
\hline \multirow{2}{*}{ Persistently Negative } & Male & 90 & 8 & 9 & 3 & 3 & 1 & 1 & 77 & 14 & 18 \\
\hline & Female & 111 & 10 & 9 & 12 & 12 & 3 & 3 & 48 & 5 & 17 \\
\hline
\end{tabular}


The S.C.A.T. results showed a slightly higher incidence in males which is more in keeping with the expected number.

A past history of polyarthritis was obtained in five males and seven females outside the area, compared with three males and five females within the area (Table X).

Although the overall incidence of rheumatoid arthritis was slightly lower outside the area, it was still greater than would have been expected, and again showed an earlier onset than in population studies. It was felt that there was no real difference between the two samples, so that the results of the main study are unlikely to have been influenced by using probands and relatives in the immediate vicinity of the hospitals.

\section{Discussion}

It is clear from this data that, as a group, the relatives of patients with Still's disease differ in certain respects from the general population. Not only do they have a greater incidence of clinical inflammatory polyarthritis but radiologically they also show a greater frequency of sacro-iliitis and of erosive arthritis in the hands and feet. As the controls were drawn from a different area, this might merely represent a regional difference, but a comparison of seven population samples in Northern Europe has not shown any marked regional differences (Lawrence, Laine, and de Graaff, 1961).

A striking feature is the relative excess of sacroilitis in the male relatives and of peripheral erosive changes in the female relatives. The excess of radiological sacro-iliitis in the male relatives would appear to be associated with the findings both of Whittinghill and others (1958) and ourselves of a relatively high prevalence of clinical spondylitis in the relatives of probands with Stili's disease.

Our findings as a whole would suggest that Still's disease depends on a double inheritance of alleles associated with both spondylitis and peripheral polyarthritis. In this connexion it is of interest that we have now encountered spinal limitation $\frac{\mathbb{1}}{3}$ at the most recent follow-up in three patients, all resident outside the area studied in detail, who were originally diagnosed as cases of Still's disease. $\Rightarrow$

A surprising finding is the small proportion of $\stackrel{\oplus}{\stackrel{5}{?}}$ positive sheep cell agglutination tests in the relatives. 을 In this respect the relatives of cases of Still's disease $\frac{\bar{O}}{\bar{N}}$ differ markedly from the families of patients with $\frac{\bar{\omega}}{\overrightarrow{0}}$ adult rheumatoid arthritis, in whom a relatively $\stackrel{\circ}{\propto}$ high proportion of positive tests has been encoun- $ळ$ tered (Ziff, Schmid, Lewis, and Tanner, 1958; $\vec{\circ}$ Lawrence and Ball, 1958). It is particularly remarkable that none of the relatives of the sero- $\vec{\omega}$ positive Still's probands had a positive sheep cell test. It has been suggested (Lawrence, 1961) that, $\frac{\bar{\alpha}}{\alpha}$ in adult rheumatoid arthritis, there are two genetic i factors, one for the serum factor and the other for the $\vec{\omega}$ arthritic manifestations, and it is possible that the $N$ latter may be identical with the peripheral joint $\vec{\omega}$ genetic factor in Still's disease.

In view of the absence of positive sheep cell tests in the relatives of sero-positive patients with Still's $\mathbb{D}$ disease, it must be assumed that the serum factor in $\frac{\mathbb{D}}{O}$ Still's disease is not genetically determined and it $\frac{\Phi}{3}$ would seem likely that it is, in fact, secondary to the disease process. This is confirmed to some extent by a connexion which has been noted between the S.C.A.T. in probands and the severity of the disease but this relationship could equally be explained effect of the S.C.A.T. on prognosis (Table XI)

\section{TABLE XI}

RELATIONSHIP OF S.C.A.T. IN 93 PROBANDS TO COURSE OF DISEASE AT TIME OF SURVEY (1960)

\begin{tabular}{|c|c|c|c|c|c|}
\hline \multirow{2}{*}{ S.C.A.T. } & \multicolumn{4}{|c|}{ Course of Disease } & \multirow{2}{*}{$\begin{array}{l}\text { Total } \\
\text { Cases }\end{array}$} \\
\hline & Mild & Moderate & Severe & Dead & \\
\hline Positive & $\mathbf{0}$ & 2 & 5 & 1 & 8 \\
\hline $\begin{array}{c}\text { Transient } \\
\text { Positive }\end{array}$ & 2 & 6 & 11 & 0 & 19 \\
\hline Negative & 16 & 29 & 19 & 2 & 66 \\
\hline
\end{tabular}

TABLE $\mathbf{X}$

CLINICAL POLYARTHRITIS IN PARENTS AND SIBLINGS OF PROBANDS WITH STILL'S DISEASE IN AREA OF SURVEY AND FROM ELSEWHERE IN GREAT BRITAIN

\begin{tabular}{|c|c|c|c|c|c|c|c|c|c|c|c|}
\hline \multirow{2}{*}{\multicolumn{3}{|c|}{$\begin{array}{c}\text { Sex of } \\
\text { Relatives }\end{array}$}} & & \multicolumn{4}{|c|}{ Inside Area of Survey } & \multicolumn{4}{|c|}{ Outside Area of Survey } \\
\hline & & & & Total & $\begin{array}{c}\text { Poly- } \\
\text { arthritis }\end{array}$ & $\begin{array}{c}\text { Past } \\
\text { Polyarthritis }\end{array}$ & $\begin{array}{l}\text { S.C.A.T. } \\
1: 32+\end{array}$ & Total & $\begin{array}{c}\text { Poly- } \\
\text { arthritis }\end{array}$ & $\begin{array}{c}\text { Past } \\
\text { Polyarthritis }\end{array}$ & $\underset{1: 32+}{\text { S.C.A.T. }}$ \\
\hline Male & .. & . & .. & 107 & 8 & 3 & 1 & 133 & 6 & 5 & 5 \\
\hline Female & .. & .. & $\ldots$ & 121 & 7 & 5 & 3 & 134 & 5 & 7 & 4 \\
\hline
\end{tabular}


A genetic factor in the sheep cell test cannot, however, be altogether excluded, as the siblings in this study may have been too young to have developed sero-positivity. Bywaters, Carter, and Scott (1959b) have shown that the S.C.A.T. varies with age in rheumatoid arthritis as it does in the general population (Lawrence and others, 1961). Since the inheritance of the sheep cell factor appears to be polygenic, the parents and grandparents would be less likely to show the trait.

Environmental causes of the familial aggregation encountered in this study cannot be altogether excluded, but our experience with twins is against this. Four pairs of twins occurred in our 93 probands. In only one pair were both twins affected and this pair was monozygous. One other pair was also monozygous, the remaining two pairs in the survey area being dizygous. In our total series of patients with Still's disease seen at Taplow, there were three further pairs of twins; two of these were monozygous and in one of these pairs both twins were affected.

\section{Summary}

(1) The siblings, parents, and grandparents of a series of 93 patients with Still's disease were examined clinically and radiologically and their serum was submitted to the sheep cell agglutination test.

(2) Of the 304 relatives living within 15 miles of the Canadian Red Cross Memorial Hospital, Taplow, and within 10 miles of Hammersmith Hospital, 277 were examined, and these were compared with random population samples examined in the same way in Leigh and Wensleydale. Clinical evidence of definite inflammatory polyarthritis was found in nine of 120 male relatives and in thirteen of the 157 female relatives, the expected numbers being four males and eight females. Of the nine males with polyarthritis, four were diagnosed as cases of spondylitis and one of gout. The remaining males and all the females were diagnosed as cases of rheumatoid arthritis.

(3) Radiological evidence of erosive arthritis in the hands was found four times as frequently in the female relatives as in a control group of females of identical age distribution.

(4) Sacro-iliitis was three times as common in the male relatives as in the controls.

(5) A positive S.C.A.T. was found less often in the relatives than in the random sample.

(6) A double inheritance associated with spondylitis and sero-negative peripheral arthritis might perhaps account for these findings.
We should like to thank Dr. J. Ball, Mr. R. Finnigan, Dr. F. E. T. Scott, and Mr. A. Reading for carrying out the S.C.A.T.s in duplicate, and Prof. R. E. Steiner and Dr. C. W. C. Gough for the use of their $x$ ray departments.

\section{REFERENCES}

Ball, J. (1950). Lancet, 2, 520.

Bywaters, E. G. L., Carter, M., and Scott, F. E. T. (1959a). Ann. rheum. Dis., 18, 225.

$-\longrightarrow,-,-(1959 \mathrm{~b})$. Ibid., 18, 233.

Hollister, L. E., and Engleman, E. P. (1958). J. chron. Dis., $8,334$.

Kellgren, J. H., and Lawrence, J. S. (1957a). Ann. rheum. Dis., 16, 494. (1957b). Ibid., 16, 485.

Lawrence, J. S. (1961). Ibid., $20,11$. and Ball, J. (1958). Ibid., 17, 160. and Bennett, P. H. (1960). Ibid., 19, 20.

_- Laine, V., and de Graaff, R. (1961). Proc. roy. Soc. Med., 54, 454.

McEwen, C., Ziff, M., Carmel, P., Ditata, D., and Tanner, M. (1958). Arthr. and Rheum., 1, 481.

Rose, H. M., Ragan, C., Pearce, E., and Lipman, M. O. (1948). Proc. Soc. exp. Biol. (N.Y.), 68, 1.

Sharp, J., Purser, D. W., and Lawrence, J. S. (1958). Ann. rheum. Dis., 17, 303.

Whittinghill, M., Hendricks, E. E., Taylor, G. S., and Thorp, L. S. (1958). "Proc. X International Congress of Genetics, Montreal, 1958", vol. 2: Abstracts, p. 314. University of Toronto Press, Ontario, Canada.

Ziff, M., Schmid, F. R., Lewis, A. J., and Tanner, M. (1958). Arthr. and Rheum., 1, 392.

Discussion.-Prof. J. H. Kellgren (Manchester): This was a very fascinating paper. Did any of the probands have iritis?

Dr. ANSEll: Yes. Six have had iritis, but we have not analysed these separately because, until we have completed the Watford Survey, we have nothing with which to compare them. The iritis is not necessarily related to sacro-iliitis; only two have definite sacro-iliac abnormality.

DR. J. J. DE BléCourt (Groningen): Do you think the sacro-iliitis you have found in Still's disease is the same as that seen in classical ankylosing spondylitis?

Dr. ANSEll: I am not able to answer this. Two relatives had classical ankylosing spondylitis, and another two appeared to have a mixture of severe peripheral arthritis and sacro-iliac changes. The sacro-iliac changes found in the probands is associated with quite marked peripheral arthritis, and it is not yet known whether any will have ankylosing spondylitis. We have two patients in our present follow-up series of cases of Still's disease who have gone on to develop ankylosing spondylitis. Only time will give the answer.

The President: Was either sero-positive?

Dr. ANSEll: No, neither. 
Prof. Bywaters: The value of a study like this continues to grow with time and we hope to be able to expand the investigation in various directions in the future.

\section{Etude familiale de la maladie de Still}

\section{RÉSUMÉ}

(1) Les frères, soeurs, parents et grands-parents de 93 sujets atteints de la maladie de Still furent examinés cliniquement et radiologiquement et leurs sérums soumis à la réaction d'agglutination des globules de mouton.

(2) Sur 304 parents habitant dans un rayon de 15 milles du Canadian Red Cross Memorial Hospital (Taplow) et de 10 milles du Hammersmith Hospital (Londres), 277 furent examinés et comparés à un échantillon de la population examiné de la même manière à Leigh at à Wensleydale. Des signes cliniques de polyarthrite inflammatoire définie furent trouvés chez 9 sur 120 parents masculins et chez 13 sur 157 parentes, alors que, statistiquement, on aurait dû trouver $4 / 120$ et $8 / 157$ respectivement, dans la population ordinaire. Parmi les 9 hommes polyarthritiques on reconnut 4 cas de spondylarthrite et un cas de goutte. Les autres hommes et toutes les femmes furent atteints d'arthrite rhumatismale.

(3) Signes radiologiques d'arthrite érosive des mains furent trouvés quatre fois plus souvent chez les parentes des malades que chez des femmes témoins d'âges correspondants.

(4) L'atteinte sacro-iliaque fut trois fois plus fréquente chez des parents mâles que chez les témoins.

(5) La réaction d'agglutination des globules de mouton fut moins souvent positive chez les parents que chez les témoins.
(6) Une hérédité double, associée à la spondylarthrite et à l'arthrite périphérique séro-négative pourrait peut-être expliquer ces résultats.

\section{Estudio familial de la enfermedad de Stil}

\section{SUMARIO}

(1) Hermanos, parientes y abuelos, de ambos sexos, $\frac{\bar{O}}{\overline{\frac{O}{N}}}$ de 93 pacientes con enfermedad de Still fueron exami- $\frac{\Phi}{\partial}$ nados clínica y radiológicamente y sus sueros fueron $\Phi$ sometidos à la reacción de aglutinación de los eritrocitos
de cordero.

(2) Dentro de 15 millas del Canadian Red Cross $\vec{\circ}$ Memorial Hospital, Taplow, y dentro de 10 millas del Hammersmith Hospital, Londres, vivían 304 dichos $\overrightarrow{\vec{\omega}}$ parientes; 277 de estos fueron examinados y comparados a una muestra de la población similarmente examinada en Leigh y en Wensleydale. Evidencia clínica de poliartritis inflamatoria definida fué encontrada en 9 de los î 120 parientes masculinos y en 13 de las 157 parientes, $\overrightarrow{-}$ las cifras anticipadas siendo cuatro machos $y$ ocho $\omega$ hembras. De los 9 hombres con poliartritis, 4 fueron $N$ casos de espondilartritis y uno de gota. Los demás hombres $\mathrm{y}$ todas las mujeres fueron diagnosticados como casos de artritis reumatoide.

(3) Datos radiológicos de artritis erosiva de las manos $\vec{c}$ fueron encontrados cuatro veces más frecuentemente $\mathbb{D}$ en las parientes que en las testigos de edades correspondientes.

(4) Lesiones sacro-iliacas fueron tres veces más $\bar{\partial}$ frecuentes en los parientes que en los testigos.

(5) La reacción de aglutinación de eritrocitos de cordero fué menos frecuentemente positiva en parientgs (de ambos sexos) que en testigos.

(6) Una doble herencia, asociada a la espondilartritis y a la artritis periférica sero-negativa podría quizas explicar estos resultados. 